\title{
Metabolism of Cardiac Structural Proteins in Normal and Hypertrophied Rabbit Heart
}

\author{
Ken Ebisawa, M.D., Yuji Kira, M.D., \\ Tadahiro Korzumi, M.D., Yoshio Iто, M.D., \\ and Etsuro Ogata, M.D.
}

\section{SUMmary}

In an attempt to elucidate the characteristics of the metabolic response of the hypertrophying heart, the rates of amino acid incorporation into cardiac structural proteins were studied in female rabbit hearts in vivo by use of a pulse-label isotope ( ${ }^{3} \mathrm{H}$-lysine) method. Hypertrophy of the left ventricle was produced by applying mild aortic constriction. Structural proteins were separated from the heart excised $24 \mathrm{~h}$ after the pulse, and the rate of ${ }^{3} \mathrm{H}$ incorporation was calculated as $\mathrm{cpm}{ }^{3} \mathrm{H} / \mathrm{mg}$ lysine of the protein. In the control (without aortic constriction), left ventricular structural proteins exhibited the following relative incorporation rate (the rate in actin being taken as 1.0): native tropomyosin, $2.79 \pm 0.38$ (mean $\pm \mathrm{SE}$, $\mathrm{n}=5$ ); 10S-actinin and $\alpha$-actinin complex, 2.52 \pm 0.29 ; heavy chain of myosin, 2.09 \pm 0.25 ; light chain of myosin, $1.82 \pm 0.28$; soluble protein, 1.79 \pm 0.30 ; and actin, 1.0. In the rabbits with aortic stenosis the rates of amino acid incorporation showed a striking increase up to 7 days after surgery, and declined to the control level by 1 month. Among the protein fractions, native tropomyosin and the light chain of myosin showed a much higher rate of isotopic incorporation during the earlier phase of the response. These results seem to indicate the presence of a unique pattern of metabolic response in cardiac muscle confronted with a workload.

\section{Additional Indexing Words:}

Rabbit heart Hypertrophy Aortic constriction Structural proteins Protein synthesis

7 HE heart responds to a workload with an increase in its own mass. ${ }^{1,21}$ This may result from alterations in protein synthesis and/or degradaTokyo.

From the Fourth Department of Internal Medicine, Faculty of Medicine, University of Tokyo,

This work was supported in part by a grant from the Japanese Ministry of Education, Science, and Culture.

Address for reprint: Ken Ebisawa, M. D., Fourth Department of Medicine, Faculty of Medicine, University of Tokyo, 3-28-6 Mejirodai, Bunkyo-ku, Tokyo 112, Japan.

Received for publication December 8, 1981 . 
tion. Accumulating evidence indicates that in pressure-induced cardiac hypertrophy, synthesis of proteins is enhanced in general, while degradation remains unchanged. ${ }^{1,3)-5}$ ) Because muscle protein consists of heterogeneous fractions and turns over at non-uniform rates, ${ }^{6 /-10)}$ it seems reasonable to study individual protein fractions during the metabolic response of the cardiac muscle. Several investigators have described an increase in the synthesis of myosin in the hypertrophying heart. ${ }^{3,8), 11)}$ However, details of the myosin subfractions and other structural proteins have yet to be analyzed in the hypertrophying heart.

In the present research we measured the rate of isotope ( ${ }^{3} \mathrm{H}$-lysine) incorporation in vivo into several structural proteins in normal and hypertrophying rabbit heart.

\section{Methods}

\section{Animals and administration of radioactive lysine}

Adult female rabbits weighing approximately $3 \mathrm{Kg}$ were used. They were raised on conventional laboratory rabbit food and tap water ad lib. In some rabbits, aortic coarctation was produced surgically under sodium pentobarbital anesthesia ( $30 \mathrm{mg} / \mathrm{Kg}$, iv); the ascending aorta was constricted to $3 / 4$ of its original circumference by applying a vinyl thread from the outside. Experiments with appropriate controls were performed at the times after operation as indicated in the text. The animals were allocated randomly. In the morning of the experiment (about $10.00 \mathrm{~h}$ ) the animals were injected intravenously with $100 \mu \mathrm{Ci} / \mathrm{Kg}$ of ${ }^{3} \mathrm{H}$-lysine (containing $97.5 \mathrm{Ci} / \mathrm{mM}$ ) and sacrificed at the times after injection as indicated in the text. After exsanguination under sodium pentobarbital anesthesia $(30 \mathrm{mg} / \mathrm{Kg}$, iv), the heart and back muscle were excised. The left ventricular muscle with septum, right ventricular muscle, and atrial muscle were separated from the heart. These specimens were kept frozen at $-20^{\circ} \mathrm{C}$.

\section{Preparation of muscle proteins}

The structural proteins were extracted at $4^{\circ} \mathrm{C}$ by the methods of Ebashi and Sugita ${ }^{12)-14)}$ with minor modifications. In short, to 1-10 Gm of minced muscle was added 9 volumes of $0.1 \mathrm{M} \mathrm{NaCl}$ and $5 \mathrm{mM} \mathrm{NaOH}$ solution. The mixture was homogenized for $30 \mathrm{~min}$ in a Waring blender and the homogenate was centrifuged in a Tomy No. 5 rotor at $15,000 \times g$ for $10 \mathrm{~min}$. The supernatant was mixed with trichloroacetic acid (10\% in final) and centrifuged. The resulting precipitate was neutralized with $\mathrm{NaOH}$, dialyzed against $2 \mathrm{mM} \mathrm{NaHCO}_{3}$, and used as the soluble protein fraction. For the preparation of structural protein, the residue was resuspended in $0.1 \mathrm{M} \mathrm{NaCl}$ and 
$2 \mathrm{mM} \mathrm{NaHCO}$ solution and centrifuged at $15,000 \times g$ for $10 \mathrm{~min}$. The same procedure was repeated 5 times. The final residue was dissolved in $1.0 \mathrm{M}$ $\mathrm{NaCl}$ and $2 \mathrm{mM} \mathrm{NaHCO}$ solution and centrifuged at $15,000 \times g$ for $30 \mathrm{~min}$. The supernatant was dialyzed exhaustively against $2 \mathrm{mM} \mathrm{NaHCO}$, and used as the structural protein preparation, myosin B. This myosin B was centrifuged in a Hitachi RP 30 rotor at $68,000 \times g$ for $90 \mathrm{~min}$ in low ionic strength medium. One hundred $\mathrm{ml}$ of the supernatant was mixed with $20 \mathrm{Gm}$ of $\left(\mathrm{NH}_{4}\right)_{2} \mathrm{SO}_{4}$ and centrifuged at $15,000 \times g$ for $10 \mathrm{~min}$. The resulting precipitate was collected, dialyzed against $2 \mathrm{mM} \mathrm{NaHCO}$, and used as the complex of $10 \mathrm{~S}$-actinin and $\alpha$-actinin fraction. Native tropomyosin was precipitated by adding another $20 \mathrm{Gm}$ of $\left(\mathrm{NH}_{4}\right)_{2} \mathrm{SO}_{4}$ to $100 \mathrm{ml}$ of its original volume after extraction of $10 \mathrm{~S}$-actinin and $\alpha$-actinin complex, and dialyzed against $2 \mathrm{mM}$ $\mathrm{NaHCO}_{3}$. The residue obtained after the ultracentrifugation at $68,000 \times g$ in the above procedure was washed 8 times with $2 \mathrm{mM} \mathrm{NaHCO}_{3}$ solution to exclude trace contamination of native tropomyosin. The heavy chain of myosin, light chain of myosin, and actin were isolated from this native tropomyosin-free myosin B by a block gel electrophoretic method ${ }^{15}$ ) as follows. First, the native tropomyosin-free myosin B was dissolved in $30 \mathrm{ml}$ of $2 \%$ sodium dodecyl sulfate (SDS), $1 \% \beta$-mercaptoethanol and $10 \mathrm{mM}$ phosphate buffer $(\mathrm{pH} 7.0)$ solution, and left for $24 \mathrm{~h}$ at room temperature. Then $10 \mathrm{ml}$ of glycerin and $1 \mathrm{ml}$ of $0.05 \%$ bromophenol blue were added. To polymerize the gel, a second solution was made consisting of $1 \mathrm{ml}$ of dimethylaminopropionitrile added to $650 \mathrm{ml}$ of a solution containing $10 \%$ acrylamide, $0.1 \%$ SDS, $25 \mathrm{mM}$ Tris base, $0.192 \mathrm{M}$ glycine buffer ( $\mathrm{pH} 8.6$ ), and $487.5 \mathrm{mg}$ of ammonium persulfate. The second solution was transferred to a $3 \mathrm{~cm} \times 15 \mathrm{~cm} \times 18$ cm block gel apparatus. Reservoir buffer containing $25 \mathrm{mM}$ Tris base, 0.192 $\mathrm{M}$ glycine (pH 8.6), and $0.1 \%$ SDS was layered on the top of the sample to fill the apparatus. Electrophoresis was performed at $150 \mathrm{~mA}$ for $8 \mathrm{~h}$. Three pieces of strips were cut from the block gel and stained in Coomassie brilliant blue solution to find the respective positions of the bands of myosin heavy chain, the two light chains, and actin. The gels containing the myosin heavy chain, the light chain, and the actin were individually excised according to the positions of the stained bands. The heavy chain was eluted from the gel into a $0.05 \%$ SDS and $0.05 \mathrm{M} \mathrm{NH}_{4} \mathrm{HCO}_{3}$ solution. ${ }^{16}$ ) The light chain and the actin were separately collected from the gels by electrophoresis. The three fractions were precipitated by trichloroacetic acid (10\% in final), neutralized with $\mathrm{NaOH}$, and dialyzed against $2 \mathrm{mM} \mathrm{NaHCO}$.

\section{Radioactivity measurements}

The radioactivity of these fractions was measured in an Intertechnique SL-31 liquid scintillation counter. The scintillation fluid was composed of 
$6 \mathrm{Gm}$ of 2,5-diphenyloxazole, $0.4 \mathrm{Gm}$ of $\rho$-bis-[2-(phenyloxazolyl)]-benzene, and $167 \mathrm{ml}$ of Isolab Scintisol-GP solubilizer per liter of toluene. Two samples were prepared from each specimen and each sample was counted twice for $20 \mathrm{~min}$. Correction was made for quenching. The averaged values were used. The rate of lysine uptake was calculated as either cpm ${ }^{3} \mathrm{H} / \mathrm{mg}$ lysine of the respective protein fraction when various proteins were to be compared or $\mathrm{cpm}{ }^{3} \mathrm{H} / \mathrm{mg}$ protein when the same kind of protein was to be compared among various portions of cardiac and skeletal muscle. In some experiments the rate was described in relative terms where the rate in actin was taken as 1.0. Differences were evaluated statistically using Student's t test for groups.

Protein concentration

The protein was determined by the Lowry method with bovine serum albumin as standard.

\section{Amino acid unalysis}

The lysine content in each structural protein fraction was calculated from the results of amino acid analysis with a JLC- $6 \mathrm{AH}$ automatic amino acid analyzer (JEOL).

Electrophoresis

SDS polyacrylamide gel electrophoresis was carried out as described by Weber and Osborn. ${ }^{16)}$

\section{Materials}

The L- $\left[4,5-{ }^{3} \mathrm{H}\right]$ lysine monohydrochloride $(97.5 \mathrm{Ci} / \mathrm{mM})$ was purchased from the Radiochemical Center Ltd., Amersham.

\section{Results}

\section{Homogeneity of preparations}

The isolated fractions were of considerable purity as shown in electrophoretic studies with SDS polyacrylamide gel (Fig. 1).

Incorporation of radioactive lysine into heart muscle proteins

a. Normal heart

Five normal rabbits were sacrificed $24 \mathrm{~h}$ after the administration of radioactive lysine. Table I shows the rates of lysine uptake into various structural proteins of the left ventricle. The native tropomyosin exhibited the highest value, followed by the actinin complex. Actin showed the lowest value.

Six normal rabbits were killed 6,12 , or $24 \mathrm{~h}$ after radioactive lysine injections. The order of the rate of incorporation into each fraction was the same, irrespective of the time of sacrifice after injection (data not shown). 


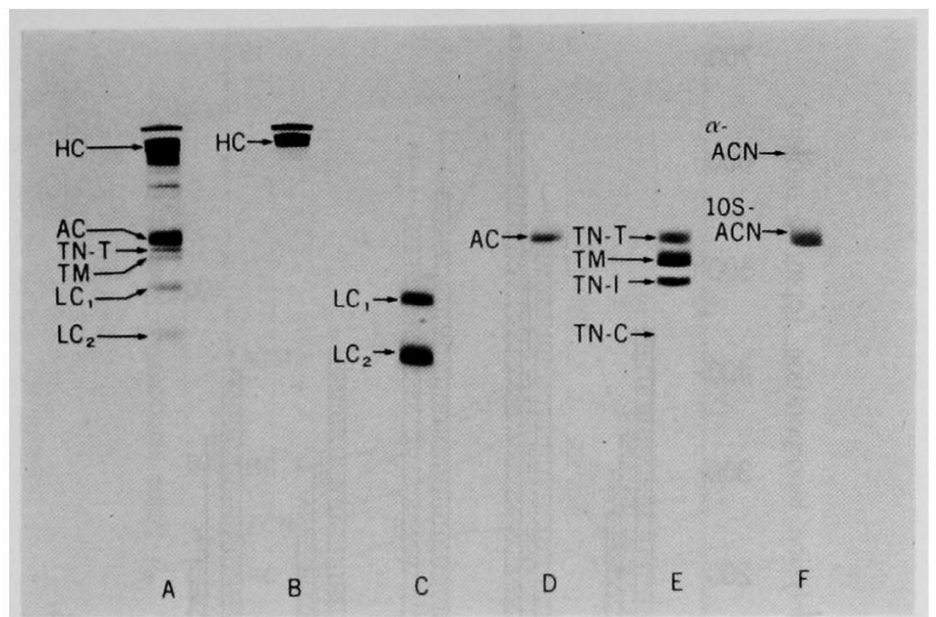

Fig. 1. SDS polyacrylamide gel electrophoresis of cardiac structural proteins. Polyacrylamide $10 \%$. A, myosin B; B, heavy chain of myosin (HC); $\mathrm{C}$, two light chains of myosin $\left(\mathrm{LC}_{1}, \mathrm{LC}_{2}\right) ; \mathrm{D}$, actin $(\mathrm{AC}) ; \mathrm{E}$, native tropomyo$\sin (\mathrm{TM}=$ tropomyosin; $\mathrm{TN}-\mathrm{T}=$ troponin $\mathrm{T} ; \mathrm{TN}-\mathrm{I}=$ troponin $\mathrm{I} ; \mathrm{TN}-\mathrm{C}=$ troponin $\mathrm{C}$ ); F, the complex of 10S-actinin (10S-ACN) and $\alpha$-actinin ( $\alpha$-ACN).

Table I. The Rate of ${ }^{3} \mathrm{H}$ Incorporation into Left Ventricular Structural Proteins in

Normal Rabbits Determined $24 \mathrm{~h}$ after Intravenous Administration of ${ }^{3} \mathrm{H}-\mathrm{lysine}$

\begin{tabular}{c|c|c|c|c|c|c}
\hline $\begin{array}{c}\text { Experi- } \\
\text { ment }\end{array}$ & Actin & $\begin{array}{c}\text { Soluble } \\
\text { protein }\end{array}$ & $\begin{array}{c}\text { Myosin } \\
\text { light chain }\end{array}$ & $\begin{array}{c}\text { Myosin } \\
\text { heavy chain }\end{array}$ & $\begin{array}{c}\text { Actinin } \\
(\alpha+10 S)\end{array}$ & $\begin{array}{c}\text { Native } \\
\text { tropomyosin }\end{array}$ \\
\hline 1 & 1.0 & 2.94 & 2.42 & 2.96 & 3.12 & 2.56 \\
2 & 1.0 & 1.68 & 1.79 & 1.98 & 2.06 & 2.10 \\
3 & 1.0 & 1.63 & 1.80 & 2.21 & 2.52 & 3.71 \\
4 & 1.0 & 1.14 & 0.80 & 1.42 & 1.72 & 1.93 \\
5 & 1.0 & 1.58 & 2.28 & 1.86 & 3.20 & 3.67 \\
\hline $\begin{array}{c}\text { mean } \pm \text { SE } \\
(\mathrm{n}=5)\end{array}$ & 1.0 & $1.79 \pm 0.30$ & $1.82 \pm 0.28$ & $2.09 \pm 0.25$ & $2.52 \pm 0.29$ & $2.79 \pm 0.38$
\end{tabular}

Values are the results from 5 normal rabbits and expressed relative to a value of 1.0 for actin. The actual rate of ${ }^{3} \mathrm{H}$ incorporation into actin was $1891 \pm 219 \mathrm{cpm} / \mathrm{mg}$ of lysine (mean $\pm \mathrm{SE}$ ).

The rates at $24 \mathrm{~h}$ were higher than those of $12 \mathrm{~h}$ (data not shown).

The rate of lysine incorporation into myosin $\mathrm{B}$ was compared among various portions of the heart and skeletal muscles (Fig. 2, normal control). The rate was $431 \pm 39 \mathrm{cpm} / \mathrm{mg}$ protein (mean $\pm \mathrm{SE}, \mathrm{n}=6$ ) for the left ventricle, $335 \pm 20$ for the right ventricle, $256 \pm 44$ for the atrium, and $131 \pm 25$ for skeletal muscle. The rate was significantly higher in the left ventricle than in the right ventricle $(p<0.025)$. The rates in cardiac muscle were higher than those in skeletal muscle $(\mathrm{p}<0.05)$.

b. Hypertrophying heart

The rabbits with the coarctated aorta were killed 3 days, 7 days, 1 month, 


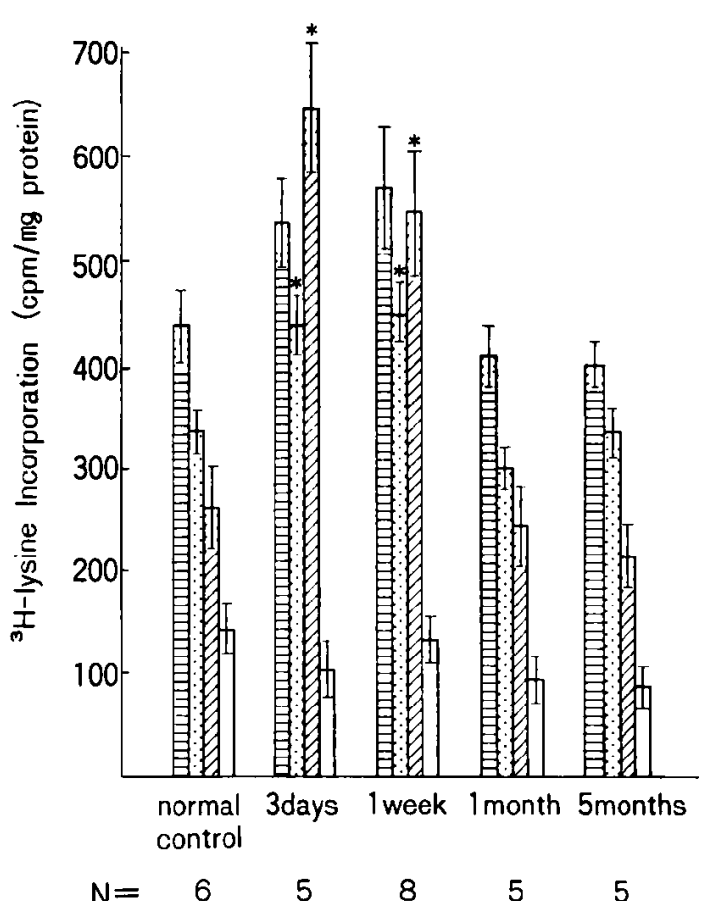

Fig. 2. The time course of changes in the incorporation rates of ${ }^{8} \mathrm{H}-\mathrm{ly}$ sine into cardiac and skeletal myosin B after aortic constriction. Comparisons are made among left ventricular, right ventricular, atrial, and skeletal myosin B. Results are given as mean $\pm \mathbf{S E}$. Horizontally striped column, left ventricular; dotted column, right ventricular; obliquely striped column, atrial; white column, skeletal myosin B. "Normal control" represents the data obtained from 6 rabbits without operation and sacrificed during the first week. The data of 6 control rabbits sacrificed 5 months thereafter are similar to and statistically not different significantly from the data of the first week. ${ }^{*} p<0.02$ (compared with normal control).

or 5 months after operation. The heart weight increased gradually after the operation, and became about twice as heavy as that of the controls in 5 months. The rate of $24 \mathrm{~h}$ lysine incorporation into the myosin $\mathrm{B}$ fraction was followed and compared among various cardiac portions and skeletal muscle. In all heart portions, a significant increase in the rate of incorporation was detectable 3 days after production of coarctation. The enhancement of incorporation subsided after 1 month (Fig. 2). Among the heart portions, the response was fastest in the myosin B of the atrium; the incorporation rate peaked on the 3 rd day, and declined thereafter. In both right and left ventricles the peak increase was observed between the 3 rd and 7 th days.

The time course of lysine incorporation into the various protein fractions of the left ventricle was followed after aortic coarctation (Fig. 3A and 3B). As 


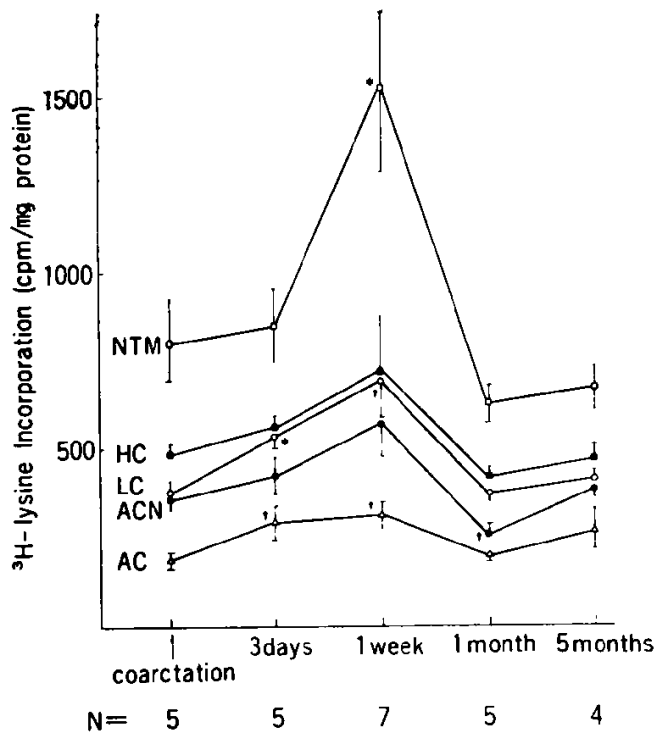

Fig. 3A. The time course of changes of the rates of ${ }^{3} \mathrm{H}-$ lysine incorporation into various structural proteins of the left ventricle after production of aortic stenosis. The data are the mean $\pm S E$. NTM = native tropomyosin ( $\square$ ); $\mathrm{HC}=$ myosin heavy chain $(\square) ; \mathrm{LC}=$ myosin light chain $(\mathrm{O}) ; \mathrm{ACN}=$ the complex of 10S-actinin and $\alpha$-actinin $(O) ; A C=\operatorname{actin}(\Delta) . \quad+p<0.05, * p<0.02$ (compared with the values before coarctation).

reflected by the incorporation into myosin $\mathrm{B}$, the rates calculated as $\mathrm{cpm}{ }^{3} \mathrm{H} /$ mg protein showed a tendency to increase in general 1 week after coarctation (Fig. 3A). However, there were some differences among various fractions. The rates of incorporation into native tropomyosin, the myosin heavy chain, and the actinin complex showed a clear sharp peak at 1 week. In contrast, the rates into the myosin light chain and actin showed a moderate but significant increase 3 days after coarctation and a further increase 1 week after coarctation. These differences are more distinct when the data are presented as percentage changes (relative rate) in the rates of ${ }^{3} \mathrm{H}$ incorporation into the structural protein fractions relative to the respective protein fractions in the controls (Fig. 3B). The rate of increase was highest in native tropomyosin, $182.5 \%$ at peak, followed by the myosin light chain. The myosin heavy chain showed the lowest rate of increase. It is remarkable that the order of relative incorporation rates was different between 3 days and 1 week after coarctation; for example, the relative rate was much higher in actin than native tropomyosin at 3 days while the converse was true at 1 week. After 1 month, incorporation rates reverted to the control level in all fractions. 


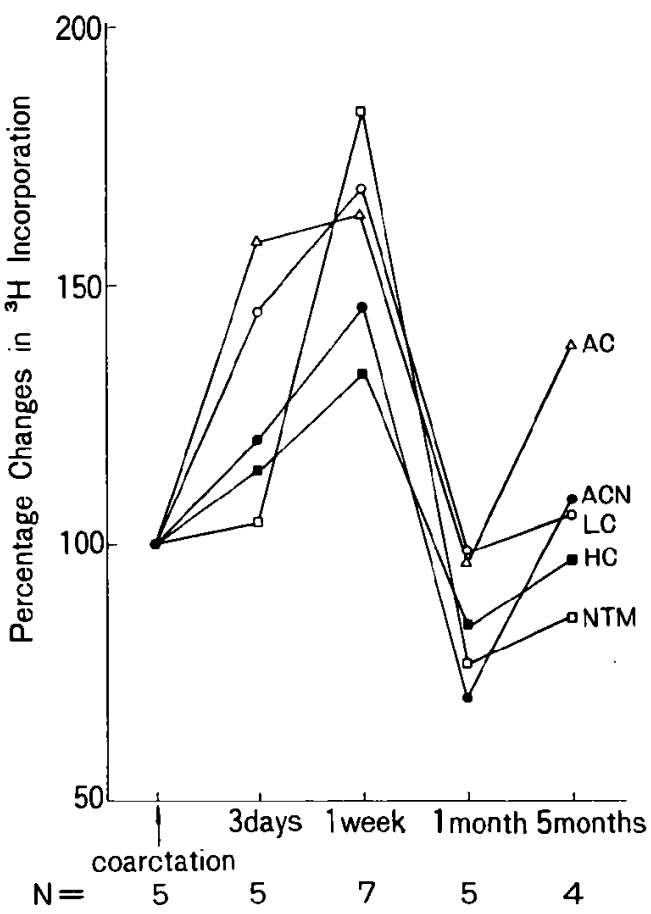

Fig. 3B. The time course of percentage changes in the rates of ${ }^{9} \mathrm{H}$ incorporation into cardiac structural proteins after aortic constriction. Values were determined $24 \mathrm{~h}$ after intravenous administration of ${ }^{3} \mathrm{H}$-lysine and are expressed as the percentage differences from the control values of the respective protein fractions. The actual rates of ${ }^{3} \mathrm{H}$ incorporation into the respective protein fractions of the control group were as follows: actin $1891 \pm 219 \mathrm{cpm} / \mathrm{mg}$ lysine; myosin light chain $3228 \pm 401 \mathrm{cpm} / \mathrm{mg}$ lysine; myosin heavy chain $3733 \pm 221 \mathrm{cpm} / \mathrm{mg}$ lysine; actinin complex $4565 \pm 404 \mathrm{cpm} / \mathrm{mg}$ lysine; native tropomyosin $5199 \pm 808 \mathrm{cpm} / \mathrm{mg}$ lysine (mean $\pm \mathrm{SE}$ ). These values were essentially identical with those of control rabbits sacrificed 5 months later.

\section{Discussion}

Since the study by Schoenheimer and his coworkers in $1939,{ }^{17}$ ) it has been known that metabolic turnover is faster in cardiac muscle than in skeletal muscle. In cardiac muscle, several investigators have reported that the turnover rate or the rate of synthesis of muscle proteins was identical for the left and right ventricles. 1),4) However the present study in rabbits has clearly demonstrated that the rate of incorporation of ${ }^{3} \mathrm{H}$-lysine administered in vivo is higher in the left ventricle than in the right ventricle when isolated structural protein (myosin B) is compared (Fig. 2). In this study, as well as various former studies of similar subjects, the rate of incorporation was interpreted as reflecting the rate of synthesis of the respective proteins. Strictly speaking this is valid only when the pool size and the activity of ${ }^{3} \mathrm{H}$-lysine in the specific loca- 
tion of protein synthesis are not altered. Because we did not have data that provided evidence for this assumption, the conclusion that synthesis is more rapid in the left than in the right ventricle is valid only with this reservation.

We further examined the rate of ${ }^{3} \mathrm{H}$-lysine incorporation into various protein fractions of the left ventricle. The order of the rates of ${ }^{3} \mathrm{H}$-lysine incorporation into lysine residues of the respective structural proteins was as follows: native tropomyosin $>$ the complex of 10S-actinin and $\alpha$-actinin $>$ myosin heavy chain $>$ myosin light chain $>$ actin (Table I). In this case, it is evident that this order of incorporation represents the order of the rate of synthesis because these proteins are to be synthesized from the same precursor pools of lysine. ${ }^{10)}$ The order was identical with that obtained in skeletal muscle of the same animal species except for the fact that in skeletal muscle soluble protein had higher and 10S-actinin had lower synthesis activities.6) It is possible that these minute differences in metabolism are a reflection of functional characteristics of the respective musculature. Yazaki and Raben $^{18)}$ described a faster degradation rate of the myosin heavy chain than that of the myosin light chain in rat hearts. Zak ${ }^{8}$ ' also showed in rats that the order of degradation of structural proteins was as follows: myosin heavy chain $=\alpha$-actinin $=$ tropomyosin $>$ myosin light chain $>$ actin. Thus, our data in rabbits confirm and extend the conclusion of these previous reports that there is a striking difference in the rate of metabolism among various structural proteins in heart muscle.

Much evidence has suggested that in the early stage of cardiac hypertrophy an increase appears in the rates of total protein synthesis, ${ }^{51,19)}$ myofibrillar protein synthesis, ${ }^{4}$ ) and myosin synthesis. ${ }^{3), 8), 111}$ In sharp contrast, this increase in synthesis seems not to be accompanied by apparent changes in protein degradation. ${ }^{1,3)-5}$ ) In the present study, an increase in the rate of ${ }^{3} \mathrm{H}$-lysine incorporation into all structural protein fractions was demonstrated soon after application of aortic stenosis. There were no definite differences in the serum levels of cold and hot lysine between the animals with and those without aortic constriction (data not shown). This was further reflected by the data on the incorporation into the skeletal muscle protein (Fig. 2). Thus the data on cardiac muscle appear to indicate an increase in the rate of synthesis of the respective proteins. However, the possibility cannot be excluded that the increase in local perfusion resulting in the rise of the specific activity of precursor amino acids in myocytes is the cause of the enhanced incorporation. In general, the extent of increase was larger in the fractions with higher basal rates. However, scrutiny discloses that the time course of the increase was somewhat different among protein fractions. The response of actin and the myosin light chain preceded that of the myosin heavy chain, actinin complex, and native tropomyosin (Fig. 3B). This can be explained from the changes in the 
rate of synthesis as well as those in the rate of degradation of respective structural proteins. $\mathrm{Zak}^{8)}$ also reported in a different workload system in rat hearts that a greater increase was observed in the synthesis of the myosin light chain than in the heavy chain. Thus it seems that the response of ventricular protein metabolism to workload is not an acceleration in general of protein synthesis but an evolution of a mechanism which leads to a special and timedependent set of changes in the synthesis and/or degradation of the component proteins.

The rate of ${ }^{3} \mathrm{H}$-lysine incorporation into myosin $\mathrm{B}$ reverted to the control level after 1 month notwithstanding the continuation of the workload on the left ventricle (Fig. 2). In the hearts with workloads the ventricular weight increased from $7.22 \pm 0.51 \mathrm{Gm}$ (mean $\pm \mathrm{SE}, \mathrm{n}=5)$ to $10.52 \pm 0.98 \mathrm{Gm}(\mathrm{n}=5$, $\mathrm{p}<0.02$ ) between 1 and 5 months while the weight in the control did not change. The yield of myosin B per unit of ventricular weight was the same in all experimental groups. Therefore, structural protein metabolism was positive in the hearts with workloads. A similar decline during chronic pressure load to the control level was observed by Gudbjarnason in the ${ }^{14} \mathrm{C}$-glycine incorporation into whole cardiac protein. ${ }^{11}$ Morkin and coworkers ${ }^{3)}$ and Everett and associates ${ }^{4}$ have reported that the specific activity of free amino acids in the cardiac tissue was not changed during these periods. These findings indicate that at least in the later phase of adaptation, deceleration of protein degradation may be the major factor for the increase in ventricular protein content. In this context, it is interesting that Meerson ${ }^{20)}$ reported that in rats in the chronic stage of cardiac hypertrophy in response to coarctation or the abdominal aorta both the rates of in vivo incorporation of ${ }^{14} \mathrm{C}$-amino acids into myofibrillar protein and its degradation decreased to a level lower than that in the controls. The reason for this discrepancy is not apparent, but differences in the species, the mode and the duration of the pressure load may be a factor.

Another interesting observation of the present study is the change in the rate of ${ }^{3} \mathrm{H}$-lysine incorporation into myosin $\mathrm{B}$ in the atria and right ventricle parallel with that in the left ventricle (Fig. 2). It is conceivable that the left atrium also suffered from a pressure load similar to that in the left ventricle. Howevar, the parallel response of the right ventricle is hard to explain. Among several possibilities for the parallel change, one explanation may be that a humoral factor or factors arising from the left ventricle caused the response in the right ventricle. Data supporting this concept will be reported in a separate paper. 


\section{Acknowledgment}

We wish to thank Mrs. T. Kuroda for her technical assistance.

\section{REFERENCES}

1. Gudbjarnason S, Telerman $\mathbf{M}$, Bing $\mathrm{RJ}$ : Protein metabolism in cardiac hypertrophy and heart failure. Am J Physiol 206: 294, 1964

2. Schreiber SS, Oratz M, Rothschild MA: Protein synthesis in the overloaded mammalian heart. Am J Physiol 211 : 314, 1966

3. Morkin E, Kimata S, Skillman JJ: Myosin synthesis and degradation during development of cardiac hypertrophy in the rabbit. Circulat Res 30:609, 1972

4. Everett AW, Taylor RR, Sparrow MP: Protein synthesis during right-ventricular hypertrophy after pulmonary-artery stenosis in the dog. Biochem J 166: 315, 1977

5. Kao RL, Rannels DE, Whitman V, Morgan HE: Factors accounting for growth and atrophy of the heart. in Recent Advances in Studies on Cardiac Structure and Metabolism, Vol 12, ed by Kobayashi T, Ito Y, Rona G, University Park Press, Baltimore, p 105, 1978

6. Koizumi $\mathrm{T}$ : Turnover rates of structural proteins of rabbit skeletal muscle. $\mathrm{J}$ Biochem (Tokyo) 76: 431, 1974

7. Swynghedauw B, Schwartz K, Léger JJ: Cardiac myosin phylogenic and pathological changes. Basic Res Cardiol 72: 254, 1977

8. Zak R: Metabolism of myofibrillar proteins in the normal and hypertrophic heart. Basic Res Cardiol 72: 235, 1977

9. Martin AF: Turnover of cardiac troponin subunits. J Biol Chem 256: 964, 1981

10. Evans CD, Schreiber SS, Oratz M, Rothschild MA: Relative synthesis of cardiac contractile proteins. Biochem J 194: 673, 1981

11. Evans C, Schreiber SS, Oratz M, Rothschild MA: Synthesis of myosin heavy and light chains in the afterloaded guinea pig right ventricle. Cardiovasc Res 12: 731, 1978

12. Ebashi S, Ebashi F: A new protein component participating in the superprecipitation of myosin B. J Biochem (Tokyo) 55: 604, 1964

13. Sugita H, Katagiri T, Shimizu T, Toyokura Y: Studies on the structural proteins in various neuromuscular diseases. in Basic Research in Myology, International Congress Series, Vol 294, ed by Kakulas BA, Excerpta Medica, Amsterdam, p 291, 1973

14. Ebashi S: Regulatory mechanism of muscle contraction with special reference to the $\mathrm{Ca}$ troponin-tropomyosin system. in Essays in Biochemistry, Vol 10, ed by Campbell PN, Dickens F, Academic Press, London, p 1, 1974

15. Nakamura S: Fractionation of proteins by disc electrophoresis - Gel slice technique-. Seibutsubutsurikagaku 17: 177, 1973 (in Japanese)

16. Weber $\mathrm{K}$, Osborn $\mathrm{M}$ : Proteins and sodium dodecyl sulfate. Molecular weight determination on polyacrylamide gels and related procedures. in The Proteins, Third Edition, Vol 1, ed by Neurath H, Hill RL, Academic Press, New York, p 179, 1975

17. Schoenheimer $\mathbf{R}$, Ratner $\mathbf{S}$, Rittenberg $\mathrm{D}$ : Studies in protein metabolism. $\mathbf{X}$. The metabolic activity of body proteins investigated with $l(-)$-leucine containing two isotopes. $\mathrm{J}$ Biol Chem 130: 703, 1939

18. Yazaki Y, Raben MS: Comparison of the synthesis of the light and heavy chains of cardiac myosin. in Recent Advances in Studies on Cardiac Structure and Metabolism, Vol 12, ed by Kobayashi T, Ito Y, Rona G, University Park Press, Baltimore, p 39, 1978

19. Schreiber SS, Oratz M, Evans C, Reff F, Klein I, Rothschild MA: Cardiac protein degradation in acute overload in vitro: reutilization of amino acids. Am J Physiol 224: 338, 1973

20. Meerson FZ, Javich MP, Lerman MI: Decrease in the rate of RNA and protein synthesis and degradation in the myocardium under long-term compensatory hyperfunction and on aging. J Mol Cell Cardiol 10: 145, 1978 